\title{
SISTEM PANAS BUMI TEMPERATUR RENDAH-SEDANG PADA CEKUNGAN KUTAI DAN REKOMENDASI PEMANFAATANNYA
}

\section{LOW-MEDIUM GEOTHERMAL SYSTEM IN KUTAI BASIN AND ITS UTILIZATION}

\author{
Andri Eko Ari Wibowo, Mochamad Nur Hadi, dan Dikdik Risdianto \\ Pusat Sumber Daya Mineral Batubara dan Panas Bumi \\ andri.wibowo@esdm.go.id
}

\begin{abstract}
ABSTRAK
Pengembangan panas bumi di Indonesia masih didominasi pada sistem panas bumi vulkanik yang digunakan sebagai pemanfaatan tidak langsung (listrik), padahal sekitar 70\% dari 357 lokasi panas bumi di Indonesia berasosiasi dengan sistem non vulkanik. Keterbasan informasi bawah permukaan berupa data sumur dan fluida reservoar serta nilai keekonomian yang rendah, menyebabkan kurang berkembangnya pemanfaatan energi panas bumi di sistem non vulkanik. Oleh karena itu, tujuan penelitian ini adalah untuk memberikan informasi tentang karakteristik kimia air panas seperti tipe, asal-usul, dan temperatur fluida di Kalimantan, khususnya Cekungan Kutai Timur, serta memberikan rekomendasi pemanfaatannya.
\end{abstract}

Terdapat lima manifestasi berupa air panas dengan temperatur mulai dari 42 s.d. $55^{\circ} \mathrm{C}$, pH netral, bertipe bikarbonat, dan terletak pada zona immature water. Karakteristik fluida di daerah panas bumi ini berkorelasi dengan litologi daerah penyelidikan yang didominasi oleh batuan sedimen. Hasil plotting nilai isotop $O^{18}$ dan $D$ menunjukkan sumber fluida panas bumi berasal dari air meteorik. Air permukaan meresap ke bawah permukaan dan akan terpanaskan oleh batuan panas yang diperkirakan timbul akibat adanya pembebanan dalam waktu yang sangat lama (geopressured), yang kemudian membentuk fluida reservoar. Temperatur reservoar diperkirakan sebesar 70 s.d. $170^{\circ} \mathrm{C}$, dengan pembentukan sistem panas buminya dipengaruhi oleh lingkungan sedimen dengan umur yang relatif sudah tua (old hydrothermal system).

Sistem panas bumi di Cekungan Kutai memiliki reservoir dengan temperatur sedang-rendah, oleh karena itu pemanfaatannya lebih sesuai digunakan untuk pemanfaatan langsung. RekomendasI pemanfaatan langsung seperti untuk akuakultur, agro industri, pariwisata, dan balneoterapi dapat diaplikasikan pada semua sistem panas bumi di Cekungan Kutai. Pada sistem panas bumi di daerah Santan Tengah, Samboja, dan Tamapole-Dondang sangat memungkinkan dimanfaatkan untuk balneoterapi terhadap penyakit peradangan tulang karena memiliki kandungan bikarbonat yang tinggi ( $>500 \mathrm{ppm})$. Ada peluang untuk pemanfaatan tidak langsung menjadi energi listrik menggunakan siklus biner, pada sistem panas bumi TamapoleDondang $\left(170^{\circ} \mathrm{C}\right)$ dan Samboja $\left(150^{\circ} \mathrm{C}\right)$.

Kata kunci: panas bumi, temperatur rendah-sedang, pemanfaatan langsung, Cekungan Kutai Timur, Kalimantan

\section{ABSTRACT}

Geothermal development in Indonesia still dominated in volcanic geothermal system which is used as indirect use utilization (electricity), whereas about $70 \%$ of 357 geothermal location in Indonesian associate with non-volcanic geothermal system. Lack of subsurface information such as well data and reservoir temperature as well as low economic value that cause geothermal utilization in non-volcanic systems are less develop. Therefore, the purpose of this research is to provide the information of geothermal fluid characteristic such as type, origin, 


\section{MAKALAH ILMIAH}

and fluid temperature in Kalimantan, especially in East Kutai Basin and also the recommendation of its utilization.

There are five hot spring manifestations with a temperature of 42 to $55^{\circ} \mathrm{C}$, neutral $\mathrm{pH}$, bicarbonate type, and located in the immature water zone. This fluid characteristics correlate with the lithology of the area which is dominated by sedimentary rocks. The results of the $\mathrm{O}^{18}$ and $D$ isotopes indicate that the source of the geothermal fluid comes from meteoric water. Meteoric water flows to subsurface and heated by hot rock from geopressured process, which then forms reservoir fluid. This old hydrothermal system has reservoir temperature is about 70 to $170^{\circ} \mathrm{C}$ with the formation of its geothermal system is affected by the sedimentary environment.

The geothermal system in the Kutai Basin has a reservoir with medium-low temperatures, therefore its utilization is more suitable for direct utilization. Recommendation of geothermal direct use such as aquaculture, agro industry, tourism, and balneoteraphy can be applied on all geothermal system in Kutai Basin. Santan Tengah, Samboja and Tamapole-Dondang are possible for balneoteraphy to heal bone-ache due to high bicarbonate concentration $1>500$ ppm). There also an opportunity to develop indirect use for electricity by using binary cycle technology in Tamapole-Dondang $\left(170^{\circ} \mathrm{C}\right)$ and Samboja $\left(150^{\circ} \mathrm{C}\right)$.

Keywords: geothermal, low-medium temperature, direct use, East Kutai Basin, Kalimantan

\section{PENDAHULUAN}

Sistem panas bumi umumnya diasosiasikan dengan gunung api atau busur vulkanik (volcanic arc). Semua sistem panas bumi di Indonesia yang sudah dikembangkan menjadi listrik berada di jalur busur vulkanik. Dari 357 lokasi panas bumi yang sudah diidentifikasi oleh Badan Geologi sampai dengan tahun 2020, sekitar $30 \%$ berkaitan dengan sistem vulkanik, yang umumnya bertemperatur tinggi. Sisanya sekitar $70 \%$ tersebar di Pulau Sulawesi, Kalimantan, dan Papua, yang umumnya merupakan sistem panas bumi bertemperatur rendah-sedang. Beberapa sistem panas bumi diantaranya terletak pada cekungan sedimen seperti di Kalimantan dan Papua. Penelitian ini difokuskan pada beberapa lokasi panas bumi yang sudah diidentifikasi pada Cekungan Kutai di Kalimantan bagian Timur yaitu di Kabupaten Kutai Kartanegara (Gambar 1).

Pengembangan sistem panas bumi temperatur rendah-sedang belum banyak diupayakan. Hal ini dikarenakan keterbatasan informasi geosain seperti karakteristik fluida, kedalaman reservoar, temperatur reservoar, dan model sistem panas bumi serta nilai keekonomian yang kurang menarik. Karakteristik sistem panas bumi temperatur rendah-sedang berbeda dengan sistem panas bumi temperatur tinggi di lingkungan vulkanik sehingga konsep eksplorasi yang dilakukan juga berbeda. Pada sistem panas bumi temperatur rendah-sedang umumnya mempunyai temperatur reservoar 100$200^{\circ} \mathrm{C}$, sehingga sistem pembangkitan listrik yang digunakan juga masih terbatas pada binary cycle. Oleh karena itu, penelitian ini bertujuan untuk mengidentifikasi sistem panas bumi non vulkanik di Cekungan Kutai berdasarkan data manifestasi permukaan serta rekomendasi pemanfaatannya.

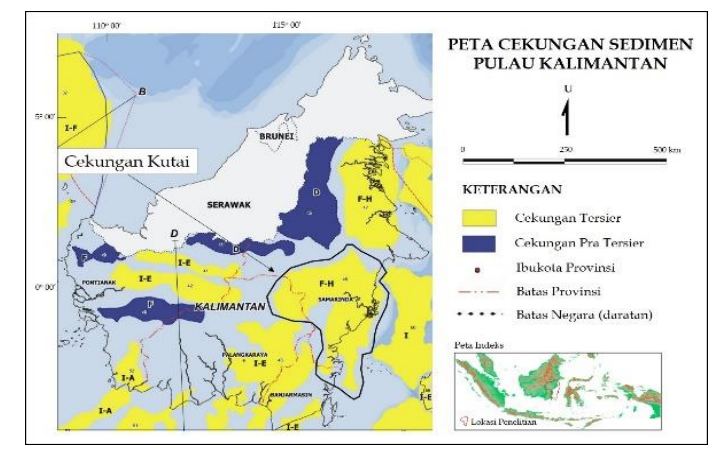

Gambar 1. Peta lokasi Cekungan Kutai (Modifikasi dari Badan Geologi, 2009) 


\section{METODOLOGI}

Metodologi yang digunakan dalam penelitian ini berupa pengamatan di lapangan, pengambilan conto, analisis laboratorium dan interpretasi data. Pengamatan yang dilakukan di lapangan meliputi pengamatan karakteristik fisik manifestasi panas bumi seperti temperatur, $\mathrm{pH}$, debit air dan daya hantar listrik. Pengambilan conto fluida berupa pengambilan conto air panas untuk selanjutnya dilakukan analisis geokimia air seperti anion, kation dan isotop di laboratorium. Pengambilan conto fluida dilakukan oleh penulis pada tahun 2018. Data cekungan geologi meliputi formasi dan struktur geologi yang digunakan merupakan data sekunder yang diambil dari beberapa literatur.

Metode analisis yang digunakan terhadap 15 unsur-unsur terlarut meliputi anion utama $\mathrm{Cl}^{-}, \mathrm{SO}_{4}{ }^{2-}, \mathrm{HCO}^{3-}$, kation seperti $\mathrm{Ca}^{2+}, \mathrm{Na}^{+}, \mathrm{K}^{+}, \mathrm{Mg}^{2+}, \mathrm{Li}^{+}$dan beberapa senyawa netral $\mathrm{SiO}_{2}, \mathrm{NH}_{3}, \mathrm{~F}, \mathrm{~B}$, secara berurutan menggunakan ion kromatografi, Atomic Absorption Spectrophotometer (AAS) dan spektrometri. Untuk mengetahui kandungan isotop stabil Deuterium dan Oksigen 18 menggunakan Mass Spectrometer (MS). Data hasil analisis laboratorium kemudian diinterpretasi sehingga karakateristik fluida yang terdapat di daerah penelitian dapat diketahui yang selanjutnya digunakan untuk pembahasan sistem panas bumi dan rekomendasi pemanfaatannya.

\section{TINJAUAN GEOSAIN}

Berdasarkan Saemundsson dkk (2011), sistem panas bumi dapat diklasifikasikan berdasarkan temperatur reservoar (temperatur tinggi, sedang, dan rendah), entalpi (entalpi tinggi dan rendah), keadaan fisik fluida (dominasi air, 2 fasa, dan dominasi uap), dan kondisi geologi. Sistem panas bumi dapat juga diklasifikasikan berdasarkan kondisi geologi yaitu (Saemundsson dkk, 2011) :
1. Volcanic geothermal system, sistem ini berasosiasi dengan aktivitas vulkanisme yang masih aktif maupun vulkanisme yang tidak aktif namun masih memiliki sisa panas. Sumber panas sistem panas bumi ini berupa intrusi atau magma.

2. Convective fracture controlled system, sumber panasnya berupa batuan panas di kedalaman pada area dengan aktifitas tektonik yang masih aktif, dengan gradient termal di atas ratarata $\left(>30^{\circ} \mathrm{C} / \mathrm{km}\right)$.

3. Sedimentary geothermal system, ditemukan di hampir semua cekungan sedimen. Sistem ini memiliki lapisan sedimen yang permeabel di kedalaman $(>1 \mathrm{~km})$ dan gradien termal di atas ratarata $\left(>30^{\circ} \mathrm{C} / \mathrm{km}\right)$. Transfer panas pada sistem ini lebih cenderung konduktif dibandingkan konvektif, walaupun dibeberapa sistem panas bumi aktifitas sesar yang lebih dominan.

4. Geopressured geothermal system, sistem ini mirip dengan terbentuknya reservoar pada minyak dan gas dimana fluida terperangkap di kedalaman dengan tekanan yang mendekati nilai tekanan litostatik.

5. Hot Dry Rock (HDR), sistem ini memiliki batuan panas dari gradien termal normal dan terletak pada kedalaman yang dalam. Nilai permeabilitasnya juga umumnya rendah dan belum bisa optimal dieksploitasi dengan metode konvensional.

6. Shallow resources, sistem ini mengacu pada aliran panas normal melalui formasi dekat permukaan dan energi panas yang tersimpan di bebatuan serta sistem air tanah hangat di dekat permukaan kerak bumi.

\section{Geologi Cekungan Kutai}

Cekungan Kutai berada di Kalimantan bagian Timur, merupakan Cekungan Sedimen Tersier terbesar $(165.000 \mathrm{~km})$ dan terdalam (12.000 s.d. 14.000 meter) di Indonesia (Gambar 1). Batas cekungan : di bagian utara tinggian Mangkalihat; di selatan basin hinges pada Adang - Flexure 
(Adang-Paternoster Fault); di barat tinggian Kuching - bagian dari Kalimantan Central Range; di bagian timur Selat Makassar (Zajuli dkk., 2015).

Cekungan Kutai mengalami subsiden pada Paleosen Akhir - Eosen Tengah hingga Oligosen, akibat basement rifting, dan menjadi tempat pengendapan Mangkupa Shale lingkungan marginal hingga open marine. Terdapat silisiklastik kasar, Beriun Sands, dalam sekuen lempung indikasi interupsi oleh pengangkatan. Subsiden berlanjut membentuk mekanisme Basin Sagging, menghasilkan endapan lempung Formasi Atan dan karbonat Formasi Kedango (Satyana dkk., 1999).

Stratigrafi Cekungan Kutai dari yang tua muda sesuai Peta Geologi Lembar Balikpapan (Hidayat dan Umar, 1994) terdiri dari:

a. Formasi Pemaluan, terdiri batupasir, serpih, perselingan batulanau dan batupasir halus, batubara, serpih, shaly coal, coaly shale.

b. Formasi Pulaubalang meliputi batupasir, serpih, batugamping, coaly shale.

c. Formasi Balikpapan tersusun oleh serpih, batupasir, batulempung dan batubara

d. Formasi Kampung baru terdiri dari batupasir, batubara, serpih, dan batulempung.

Struktur geologi yang umum dijumpai di Cekungan Kutai adalah struktur lipatan dan sesar yang berarah timurlaut - baratdaya, dimana inti antiklin didominasi oleh unit litologi batulempung. Kekar dapat berupa Shear Joint, Extensional Joint, dan Hybrid Joint dengan kondisi bukaan bisa terbuka atau tertutup oleh fracture filling mineral (Zajuli dkk., 2015).

\section{Manifestasi Panas Bumi}

Terdapat lima pemunculan manifestasi berupa air panas, yaitu air panas Santan Tengah, air panas Samboja, air panas Dondang, air panas Tamapole, dan air panas Sanga-sanga (Gambar 2).
Karakteristik fisik dari kelima manifestasi tersebut ditampilkan pada tabel 1.

Air panas Santan Tengah, terletak di Desa Santan Tengah, Kecamatan Marangkayu. Air panas berada di wilayah usaha pertambangan minyak milik PT VICO yang keluar dari bekas sumur bor minyak PT. VICO. Berdasarkan informasi masyarakat, pengeboran dilakukan pada tahun 1974 dengan kedalaman akhir 3.000 feet atau sekitar 1.000 meter. Temperatur air panas terukur sebesar $44,8^{\circ} \mathrm{C}$ dengan temperatur udara $30,4^{\circ} \mathrm{C}, \mathrm{pH} 6,2$, dan daya hantar listrik (DHL) $1.036 \mu \mathrm{s} / \mathrm{cm}$. Air panas berwarna jernih, rasa tawar, dengan debit total sebesar $2 \mathrm{lt} / \mathrm{dtk}$.

Air panas Samboja, berada di desa Sungai Merdeka, Kecamatan Samboja. Air panas Samboja muncul di kawasan Taman Nasional Bukit Bangkirai yang merupakan daerah konservasi orang utan. Air panas Samboja muncul dari rekahan bidang Sesar berarah N 310 E/65 dan rekahan patahan sekunder berarah N $240 \mathrm{E}$. Temperatur air panas di patahan utama sebesar $47,12^{\circ} \mathrm{C}$ dan di patahan sekunder $47,11^{\circ} \mathrm{C}$, dengan temperatur udara $28,84^{\circ} \mathrm{C}$. Air panas berwarna jernih, rasa tawar, dengan $\mathrm{pH} 6,38$, daya hantar listrik (DHL) $1.656 \mu \mathrm{s} / \mathrm{cm}$, dan debit 0,5 It/dtk.

Air panas Dondang, berada di desa Dondang, Kecamatan Muara Jawa, yang muncul melalui celah batuan dan ditampung dalam bak penampungan yang telah dikelola penduduk sekitarnya dengan debit relatif kecil sekitar $0,20 \mathrm{l} /$ detik dan luas manifestasi sekitar $2 \times 3 \quad \mathrm{~m}^{2}$. Karakteristik fisik air panas menunjukkan temperatur air sebesar $55,8^{\circ} \mathrm{C}$, dengan temperatur udara $36,1^{\circ} \mathrm{C}, \mathrm{pH} 8,42$, daya hantar listrik $3.520 \mu \mathrm{S} / \mathrm{cm}$, ditemukan adanya endapan oksida besi warna kecoklatan dengan kondisi air panas kurang jernih.

Air panas Tamapole, terletak di desa Tamapole, Kecamatan Muara Jawa. Air panas tersebut berada $\pm 1 \mathrm{~km}$ sebelah timur dari air panas Dondang, yang 
menurut informasi masih terdapat banyak pemunculan-pemunculan air panas lainnya di sekitar air panas Tamapole. Lokasi air panas terletak di pinggir jalan desa yang berada di areal persawahan dengan kondisi lahan yang bergambut. Temperatur air panas terukur sebesar 38 s.d. $44,98^{\circ} \mathrm{C}$ dengan temperatur udara $23,35^{\circ} \mathrm{C}, \mathrm{pH}$ 7,14, dan daya hantar listrik (DHL) 541 $\mu \mathrm{s} / \mathrm{cm}$. Air panas berwarna keruh dan berasa tawar.

Air panas Sanga-sanga, terletak di desa Sanga-sanga, Kecamatan Sanga-sanga, yang lokasi pemunculannya berada di pinggir jalan raya. Air panas keluar dari bekas sumur pemboran minyak yang kedalaman sumurnya belum diketahui. Kondisi pemunculan air panas Sangasanga mirip dengan air panas Santan Tengah, dimana air panas keluar ke permukaan akibat aktivitas pemboran minyak. Namun kondisi air panas Sangasanga terkontaminasi oleh karat dari pipa air sehingga ditemukan bau besi yang cukup kuat dan air panas yang keruh. Temperatur air panas terukur sebesar $42,47^{\circ} \mathrm{C}$ dengan temperatur udara $28^{\circ} \mathrm{C}$, $\mathrm{pH} 7,59$, dan DHL $212 \mu \mathrm{s} / \mathrm{cm}$. Air panas berwarna keruh, rasa tawar, dan berbau besi.

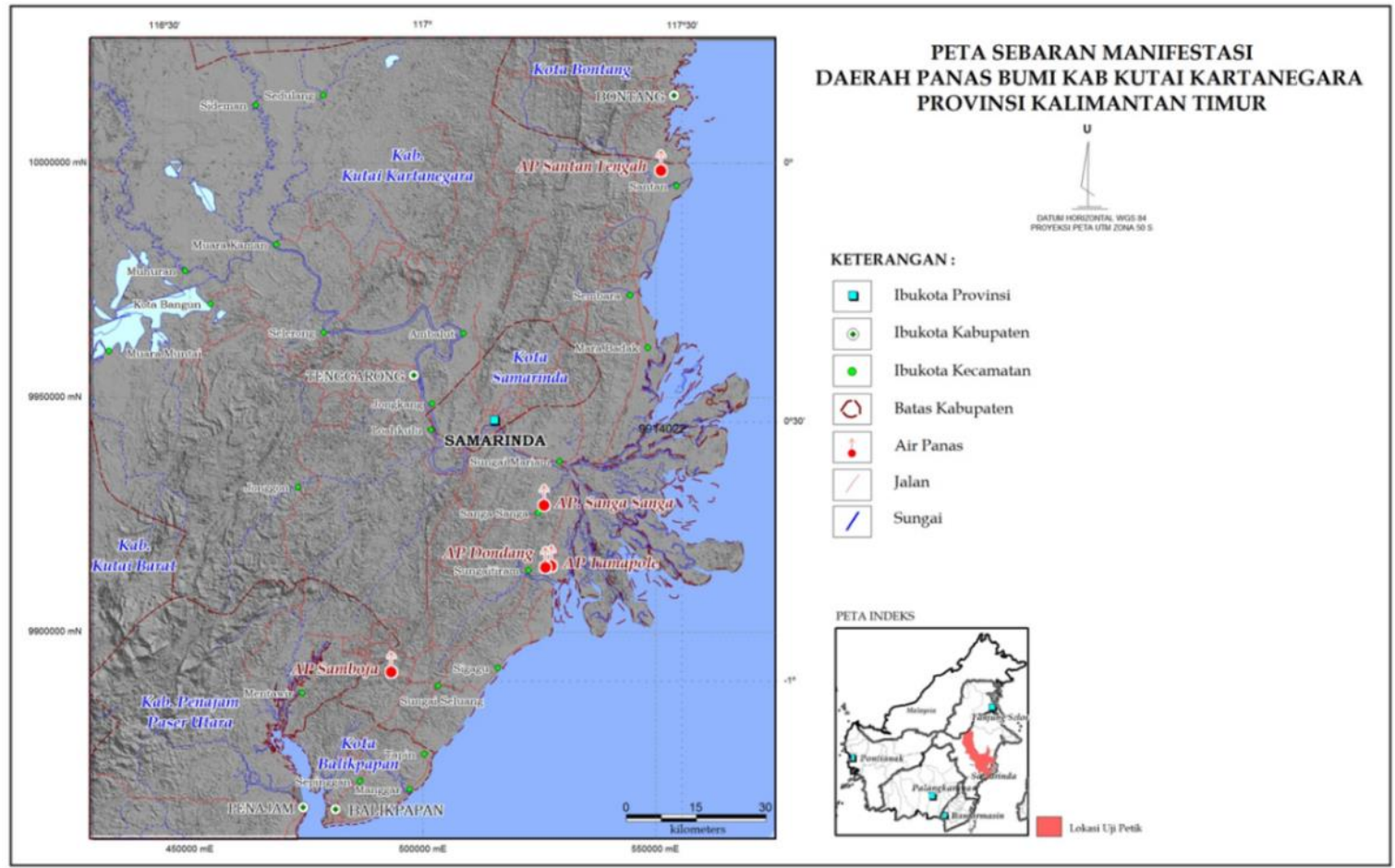

Gambar 2. Lokasi manifestasi panas bumi

Tabel 1. Karakteristik fisik manifestasi air panas

\begin{tabular}{|c|c|c|c|c|c|c|c|c|}
\hline \multirow{2}{*}{ NO } & \multirow{2}{*}{$\begin{array}{l}\text { MANIFESTASI } \\
\text { PANAS BUMI }\end{array}$} & \multicolumn{2}{|c|}{$\begin{array}{l}\text { KOORDINAT } \\
\text { (UTM) }\end{array}$} & \multirow{2}{*}{$\begin{array}{c}\mathrm{Z} \\
\text { (mdpl) }\end{array}$} & \multirow{2}{*}{$\begin{array}{c}\text { SUHU } \\
\text { AIR } \\
\left.{ }^{\circ} \mathrm{C}\right) \\
\end{array}$} & \multirow{2}{*}{$\begin{array}{l}\text { DEBIT } \\
\text { (It/dtk) } \\
\end{array}$} & \multirow{2}{*}{ pH } & \multirow{2}{*}{$\begin{array}{c}\mathrm{DHL} \\
(\mu \mathrm{S} / \mathrm{cm})\end{array}$} \\
\hline & & $(\mathrm{mT})$ & $(\mathrm{mU})$ & & & & & \\
\hline 1 & $\begin{array}{l}\text { Air Panas Santan } \\
\text { Tengah }\end{array}$ & 551270 & 9998588 & 38 & 44,8 & 2 & 6,2 & 1.036 \\
\hline 2 & Air Panas Samboja & 493364 & 9891728 & 30 & 47,12 & 0,1 & 6,38 & 1.656 \\
\hline 3 & Air Panas Dondang & 526425 & 9914022 & 12 & 55,8 & 0,2 & 8,24 & 3.520 \\
\hline 4 & Air Panas Tamapole & 527627 & 9914350 & 20 & 44,98 & - & 7,14 & 541 \\
\hline 5 & $\begin{array}{l}\text { Air Panas Sanga- } \\
\text { sanga }\end{array}$ & 526146 & 9927269 & 3 & 42,47 & - & 7,59 & 212 \\
\hline
\end{tabular}




\section{MAKALAH ILMIAH}

\section{Pemanfaatan Energi Panas Bumi}

Secara umum, pemanfaatan energi panas bumi dapat dilihat pada Gambar 3, yaitu pemanfaatan langsung (direct use) untuk sektor pariwisata, pertanian, ataupun industri dan pemanfaatan tidak langsung (indirect use) menjadi energi listrik. Pemanfaatan energi panas bumi secara langsung di dunia sudah lama berkembang sejak dahulu. Pemanfaatannya digunakan untuk pemandian air panas, pemanas ruangan, green house, pengeringan, dan lain-lain (Gambar 4). Di Indonesia, pemanfaatan langsung energi panas bumi mulai banyak dikembangkan seperti pemanfaatan untuk sektor wisata seperti pemandian air panas dan balneoterapi (terapi air panas) maupun pemanfaatan untuk sektor pertanian seperti pengeringan kopra, teh, coklat, pasteurisasi, dan perikanan.
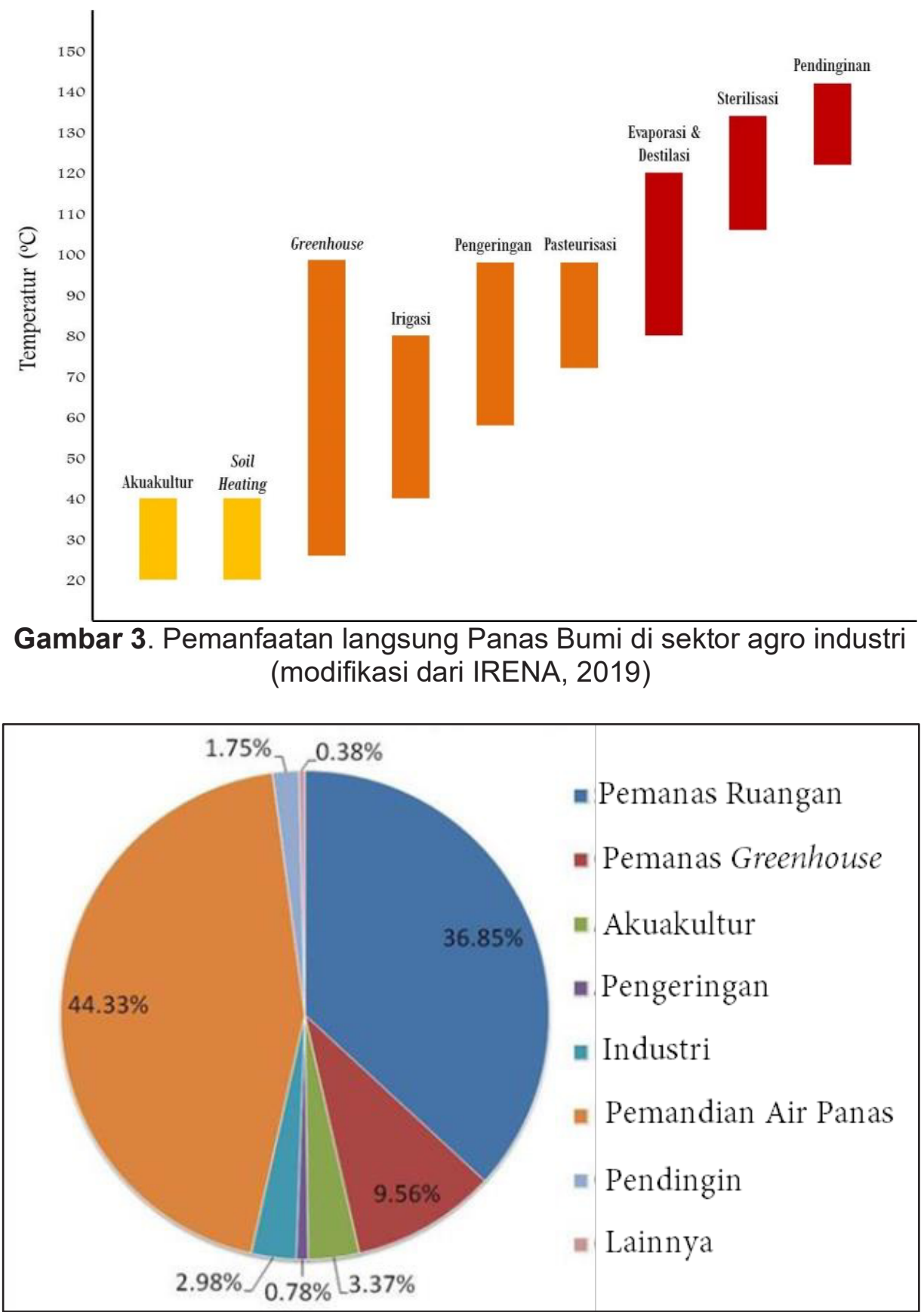

Gambar 4. Diagram pemanfaatan langsung Panas Bumi di dunia (Lund \& Boyd, 2015) 


\section{Pemanfaatan Tidak Langsung}

Secara ekonomis, fluida panas bumi bertemperatur tinggi $\left(>225^{\circ} \mathrm{C}\right)$ merupakan fluida panas yang ideal untuk digunakan dalam pembangkit listrik panas bumi dengan sistem pembangkitan konvensional. Namun dengan berkembangnya teknologi, fluida dengan temperatur rendah-sedang dapat pula dimanfaatkan menjadi energi listrik yaitu dengan binary cycle (siklus biner). Nilai ekonomis yang semakin baik, pemanfaatan sisa panas, serta terbatasnya sumber energi lain merupakan alasan penggunaan siklus biner ini. Aplikasi siklus biner dapat digunakan baik pada sumur-sumur panas bumi temperatur rendah-sedang, maupun dengan memanfaatkan air brine sisa pembangkit konvensional yang masih mempunyai panas yang tinggi. Pada prinsipnya, proses termodinamika pada siklus biner hampir sama dengan pembangkit listrik konvensional. Fluida kerja menerima panas dari fluida panas bumi melalui heat exchanger, lalu dilepaskan untuk memutar turbin yang kemudian akan menghasilkan listrik dari generator (Vaccaro, 2013). Teknologi yang banyak digunakan pada siklus biner saat ini adalah dengan siklus Kalina (Kalina Cycle) dan Organic Rankine Cycle (ORC). Perbedaan kedua teknologi ini adalah dalam penggunaan fluida kerja yang berbeda dimana Siklus Kalina menggunakan campuran air dan ammonia sedangkan ORC menggunakan fluida organik seperti iso-butana dan iso-pentana.

Siklus Kalina menggunakan fluida kerja berupa campuran ammonia dan air (Kalina dkk., 1995). Ammonia dan air mempunyai berat molekul yang mirip (ammonia 17 $\mathrm{kg} / \mathrm{mol}$, air $18 \mathrm{~kg} / \mathrm{mol}$ ), mudah larut dan mudah juga dipisahkan. Keduanya mempunyai titik didih yang berbeda, ammonia mendidih di $-33^{\circ} \mathrm{C}$ dan air di 100 ${ }^{\circ} \mathrm{C}$ (Yanagisawa dkk., 2012). Titik didih campuran ammonia dan air bervariasi tergantung rasio campurannya. Hal tersebut membuat siklus ini sangat cocok digunakan, bahkan pada sistem temperatur rendah sekalipun, karena memiliki kisaran temperatur mendidih yang besar (Renz dan Engelhard, 2006).

Pada alur proses siklus Kalina (Gambar 5), fluida kerja berupa campuran ammonia dan air, dipanasi oleh fluida panas bumi melalui mesin penukar kalor atau heat exchanger. Fluida sekunder akan menguap dan mengalir ke turbin, setelah dimanfaatkan akan dikondensasikan sebelum dipanaskan kembali oleh fluida panas bumi. Fluida panas bumi tidak dimanfaatkan langsung melainkan hanya panasnya saja yang diekstraksi, sementara fluidanya sendiri diinjeksikan kembali ke dalam reservoar (Gazo dan Lind, 2010).

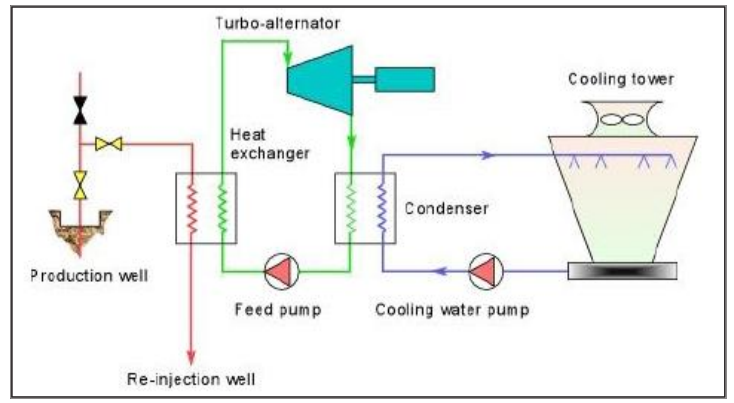

Gambar 5. Skema diagram dari siklus Kalina (Kopunicova, 2009)

Temperatur dan laju alir fluida merupakan komponen penting dalam siklus Kalina. Minimum temperatur fluida yang dapat digunakan pada siklus Kalina diperkirakan sebesar $53^{\circ} \mathrm{C}$. Namun untuk mendapatkan konversi panas yang efektif, minimum temperatur fluida adalah sebesar $80^{\circ} \mathrm{C}$ (Yanagisawa dkk., 2012). Berdasarkan hasil studi kelayakan untuk pembangkit listrik dengan siklus biner yang disusun oleh Kopunicova (2009), temperatur optimum inlet sebesar $126,4^{\circ} \mathrm{C}$ dengan laju alir $171 \mathrm{~kg} / \mathrm{s}$.

Rasio campuran air dan ammonia juga sangat penting untuk efisiensi termodinamika dan lingkungan (Mirolli dkk., 2002). Kalina dkk (1995) mengatakan rasio komposisi air dan ammonia untuk siklus Kalina sebesar 80 hingga $90 \%$ berat ammonia. Pada aplikasinya, rasio campuran air dan ammonia bervariasi tergantung temperatur inlet yang 
digunakan, yaitu $82 \%$ berat ammonia pada temperatur inlet $121^{\circ} \mathrm{C}$ (Mirolli dkk., 2002) dan $83,15 \%$ berat ammonia pada temperatur inlet $180^{\circ} \mathrm{C}$ (Kalina dkk., 1995).

Pembangkit listrik panas bumi (PLTP) pertama yang menggunakan siklus Kalina adalah Husavik yang berada di bagian utara Islandia. PLTP ini mampu membangkitkan listrik sebesar $1.700 \mathrm{~kW}$ sejak tahun 2000. PLTP dengan siklus Kalina kedua yang berproduksi adalah Unterhaching, Munchen dengan kapasitas $3.300 \mathrm{~kW}$ yang beroperasi sejak tahun 2007 dengan temperatur fluida $120^{\circ} \mathrm{C}$ dari batuan sedimen molase pada kedalaman 3,4 km (Yanagisawa dkk., 2012).

\section{Organic Rankine Cycle (ORC)} menggunakan fluida organik sebagai fluida kerjanya seperti iso-butana, iso-pentana, $\mathrm{n}$ pentana, Toluena, R134a, R123, R125, atau R600 (Darvis dkk, 2015). Titik didik senyawa organic pada fluida kerja bervariasi, dari $-146.9^{\circ} \mathrm{C}$ (nitrogen) hingga $197.96^{\circ} \mathrm{C}$ (R-11), sehingga fluida panas yang dapat digunakan pada ORC pun bervariasi dari 80 hingga $300^{\circ} \mathrm{C}$ (Hromadka dan Martinek, 2017). Beberapa keunggulan ORC ini antara lain kemampuan untuk mengekstrak energi pada temperatur rendah, efisiensi siklus dan isenptropik turbin yang tinggi, desain turbin yang sederhana, mudah dalam pengoperasian, dan daya tahan yang tinggi. Namun diantara banyak kelebihan tersebut, ada kekurangan pada ORC yaitu beberapa senyawa organik mempunyai sifat beracun dan mudah terbakar (Hromadka dan Martinek, 2017).
Pemilihan fluida kerja merupakan faktor penting untuk mendapatkan efisiensi yang tinggi di ORC. Berdasarkan analisis Darvish dkk (2015), ORC dengan menggunakan fluida kerja iso-butana dan R134a mempunyai efisensi energi tertinggi dengan fluida panas sebesar $120^{\circ} \mathrm{C}$. Sedangkan Karimi dkk (2015) menyebutkan pada temperatur $80-100^{\circ} \mathrm{C}$, ORC dengan fluida kerja R125 mempunyai nilai keekonomian yang tinggi dan efek lingkungan yang kecil.

Beberapa pembangkit listrik tenaga panas bumi (PLTP) telah menggunakan siklus biner, baik menggunakan Siklus Kalina maupun ORC. Tabel 2 menunjukkan beberapa PLTP yang sudah beroperasi menggunakan siklus biner.

\section{Pemanfaatan Langsung}

\section{Akuakultur}

Air panas bumi dapat digunakan untuk pemanfaatan budidaya perikanan pada kisaran temperatur 20 s.d. $40^{\circ} \mathrm{C}$. Prinsip dari penggunaan air panas bumi adalah mengontrol konsistensi temperatur air kolam untuk perkembang-biakan komoditas perikanan, agar dapat meningkatkan ketahanan hidup dan mempercepat perkembang-biakan. Hal tersebut sulit tercapai apabila dengan temperatur air/kolam yang tidak konsisten. Air panas tersebut digunakan untuk memanaskan air kolam melalui heat exchanger untuk mencapai temperatur yang diinginkan, ataupun dapat langsung dicampur dengan air kolam.

Tabel 2. PLTP dengan siklus biner yang sudah beroperasi di dunia (Vaccaro, 2013)

\begin{tabular}{ccccccc}
\hline No & PLTP & Lokasi & T $\left({ }^{\circ} \mathbf{C}\right)$ & Siklus Biner & Fluida Kerja & $\begin{array}{c}\text { Kapasitas } \\
\text { Terpasang (kW) }\end{array}$ \\
\hline 1 & Birdsville & Australia & 98 & ORC & Iso-pentana & 150 \\
\hline 2 & Bruchsal & Jerman & 120 & Kalina & $\mathrm{NH}_{3}-\mathrm{H}_{2} \mathrm{O}$ & 610 \\
\hline 3 & Empire & USA & 118 & ORC & Iso-pentana & 1.200 \\
\hline 4 & Fang & Thailand & 116 & ORC & Iso-pentana & 300 \\
\hline 5 & Husavik & Islandia & 124 & Kalina & $\mathrm{NH}_{3}-\mathrm{H}_{2} \mathrm{O}$ & 2.030 \\
\hline 6 & Nagqu & China & 110 & ORC & Iso-pentana & 1300 \\
\hline 7 & Unterhaching & Jerman & 122 & Kalina & $\mathrm{NH}_{3}-\mathrm{H}_{2} \mathrm{O}$ & 4.000 \\
\hline 8 & Wabuska & USA & 104 & ORC & Iso-pentana & 750 \\
\hline 9 & Wendel & USA & 103 & ORC & R114 & 2.000 \\
\hline 10 & Wineagle & USA & 110 & ORC & Iso-butana & 750 \\
\hline
\end{tabular}


Beberapa jenis ikan seperti nila, salmon atau ikan lele dapat tumbuh baik dengan mengkontrol temperatur air kolam. Beberapa ikan tropis, lobster, ataupun udang juga dapat tumbuh baik. Temperatur optimum untuk masing-masing komoditas, ditunjukkan dalam Gambar 6. Sebagai contoh ikan lele dan udang, dapat tumbuh $50 \%$ lebih baik pada temperatur antara 20 s.d. $26^{\circ} \mathrm{C}$, dan tumbuh optimum pada temperatur $32^{\circ} \mathrm{C}$, tetapi pada temperatur lebih tinggi, pertumbuhannya akan menurun.

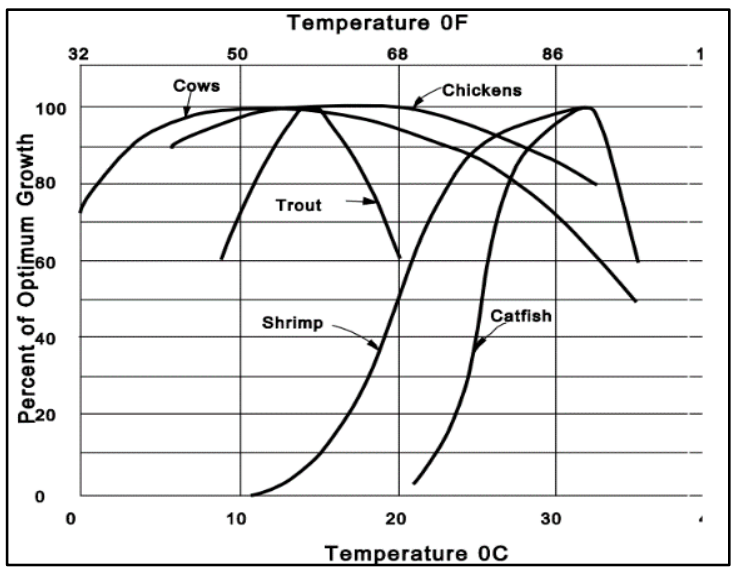

Gambar 6. Temperatur pertumbuhan untuk berbagai komoditas perikanan

Budidaya udang tropis yang dikemas dalam bentuk pariwisata sudah lama dikembangkan di New Zealand (Gambar 7). Budidaya ini menggunakan sisa fluida panas dari PLTP Wairakei. Sisa fluida tersebut tidak langsung dialirkan ke kolam karena mengandung silika yang tinggi, namun menggunakan penukar panas yang akan memanaskan air dari sungai Waikato menjadi temperatur $26^{\circ} \mathrm{C}$. Budidaya ikan lele menggunakan air panas juga sudah dilakukan di Lampung. Menurut laporan peternak di Lampung, ikan lele tumbuh sangat bagus dengan metode pencampuran air panas dengan air kolam dibandingkan dengan metode pemanasan air kolam melalui heat exchanger (Lund dan Boyd, 2015).

Selain perikanan, budidaya ganggang seperti spirulina dapat diaplikasikan pada temperatur 35 s.d. $37^{\circ} \mathrm{C}$ (IRENA, 2019).
Spirulina dan ganggang jenis lainnya dijual sebagai suplemen nutrisi kesehatan dan untuk penyembuhan medis. Sprilunia tergolong ke dalam ganggang hijau-biru yang tumbuh bagus di bawah sinar matahari yang kuat dan kondisi alkali. Di Yunani, budidaya spirulina sudah dilakukan sejak tahun 1990an. Air panas temperatur $51^{\circ} \mathrm{C}$ dialirkan sebanyak $10 \mathrm{~kg} /$ detik yang digunakan untuk memanaskan air kolam ke temperatur 33 s.d. $36^{\circ} \mathrm{C}$. Kandungan $\mathrm{CO}_{2}$ dalam air panas juga digunakan untuk meningkatkan produksi dan mengurangi biaya operasional (FAO, 2015).

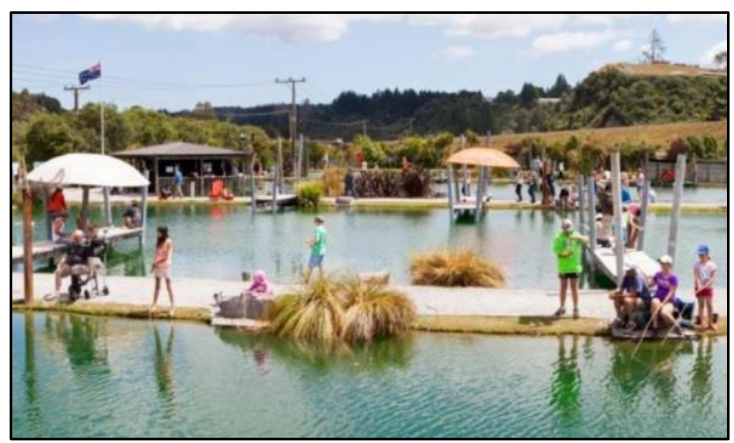

Gambar 7. Pemanfaatan budidaya udang dan pariwisata di New Zealand (https://hukaprawnpark.co.nz)

\section{Pengeringan}

Aplikasi pemanfaatan langsung panas bumi di bidang pengeringan dapat secara signifikan mengurangi konsumsi energi dan meningkatkan kualitas hasil panen. Banyak industri makanan dan pertanian menggunakan proses pengeringan untuk mempertahankan kualitas produk. Di Negara-negara maju, proses pengeringan menghabiskan 7 s.d. $15 \%$ dari total kebutuhan listrik, namun efisiensi termalnya relatif rendah sekitar 25 s.d. 50 $\%$. Bahkan di beberapa negara maju, konsumsi energinya sepertiga dari total kebutuhan listrik (Chou dan Chua dalam FAO, 2015).

Di Indonesia, aplikasi pengeringan sudah dilakukan secara intesif oleh BPPT. Sebagai contoh di Lampung untuk pengeringan coklat dan kopra, di Kamojang untuk budidaya jamur, di Lahendong untuk proses pengolahan gula aren, dan di 
Wayang Windu untuk pengeringan teh (Taufan dalam Abdullah dan Gunadnya, 2010). Pengolahan gula aren di Lahendong menggunakan 4 ton/jam air brine dari PLTP Lahendong. Temperatur yang dibutuhkan untuk proses pengeringan umumnya 60 s.d. $100^{\circ} \mathrm{C}$. Untuk pengeringan sayuran, buah, dan ikan umumnya membutuhkan temperatur 70 s.d. $95^{\circ} \mathrm{C}$ (IRENA, 2019). Tabel 3 memperlihatkan kebutuhan temperatur dan waktu pengeringan untuk beberapa komoditas di Indonesia.

Tabel 3. Temperatur dan waktu pengeringan untuk beberapa komoditas di Indonesia (Abdullah dan Gunadnya, 2010)

\begin{tabular}{|c|c|c|c|}
\hline No & Komoditas & $\begin{array}{c}\text { Temperatur } \\
\text { Pengeringan } \\
\left({ }^{\circ} \mathrm{C}\right)\end{array}$ & $\begin{array}{c}\text { Waktu } \\
\text { Pengeringan } \\
\text { (jam) }\end{array}$ \\
\hline \multirow[t]{4}{*}{1} & Coklat & & \\
\hline & - Uji lab 1 & 50 & 40 \\
\hline & - Uji lab 2 & 49,2 & 32 \\
\hline & $\begin{array}{l}\text { - Uji } \\
\quad \text { lapangan }\end{array}$ & 45,8 & 43 \\
\hline 2 & Kopi Robusta & 37 & 60 \\
\hline 3 & Vanilla & 51 & 52 \\
\hline \multirow[t]{3}{*}{4} & Benih & & \\
\hline & - Cabai & 40 & 4 \\
\hline & - Timun & 40 & 9,5 \\
\hline \multirow[t]{3}{*}{5} & Buah-buahan & & \\
\hline & - Pepaya & 39 & 33 \\
\hline & - Pisang & 40,6 & 11 \\
\hline 6 & Bayur & 39,3 & 158 \\
\hline 7 & Kemiri & 48,5 & 96 \\
\hline
\end{tabular}

\section{Pariwisata dan Balneoterapi}

Di Indonesia, pemanfaatan langsung panas bumi umumnya berupa pariwisata untuk pemandian air panas (Gambar 8). Sumber air panas bumi tidak hanya dapat digunakan sebagai tempat wisata, tetapi dapat pula dimanfaatkan lebih lanjut untuk sarana pengobatan. Terapi pengobatan dengan media air panas ini dikenal sebagai Balneoterapi. Istilah balneoterapi berasal dari kata yunani balneum yang berarti mandi. Balneoterapi sendiri berarti mandi/ berendam dengan air panas yang mengandung mineral-mineral alami. Komposisi dan karakteristik fisik masingmasing air panas umumnya berbeda, seperti air panas dengan kandungan garam tinggi, air panas kaya sulfur, kaya bikarbonat, kaya $\mathrm{CO}_{2}$, kaya radon, kaya selenium, dan lain-lainnya. Umumnya terapi pengobatan ini dikombinasikan dengan terapi fisik, hidroterapi, dan lumpur (Nasermoaddeli dan Kagamimori, 2015). Kolam-kolam terapi air panas telah dimanfaatkan sejak lama di Indonesia, namun informasi jenis penyakit dan metode pengobatannya belum banyak diketahui.

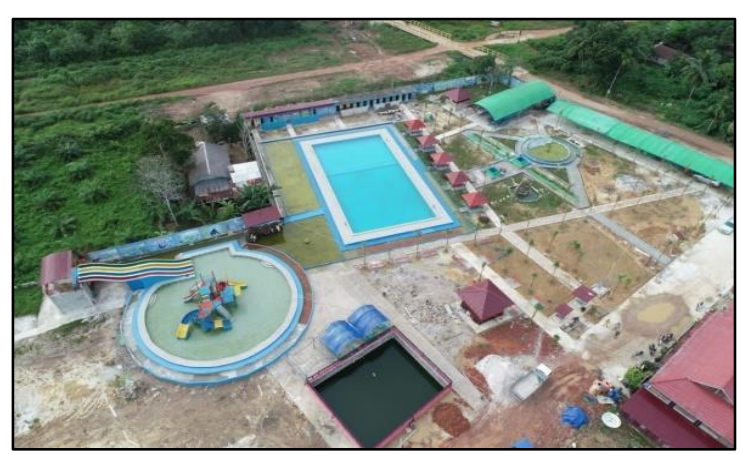

Gambar 8. Pemanfaatan langsung panas bumi untuk pemandian air panas di Kabupaten Kutai Kartanegara (sumber: Dinas ESDM Kabupaten Kutai Kartanegara)

Hasil kajian para pakar sudah banyak di publikasikan. Siswowidjojo (2012) mengatakan bahwa berendam di dalam air panas alami dapat memulihkan kesehatan dari berbagai gangguan pada saluran pencernaan, saluran urin, vascular, cordial ailment dan beberapa jenis gangguan organ kandungan akibat dari terserapnya unsur kimia mineral oleh tubuh melalui kulit. Berendam di air panas alami memberikan efek positif bagi penderita sakit kencing manis, diantaranya penurunan kadar gula dalam darah dan metabolical endocrine function. Mata air panas alami yang mengandung $\mathrm{CO}_{2}$ yang bersumber di daerah vulkanik dapat digunakan untuk penyembuhan kelainan fungsi jantung (cardiovascular disorders), khususnya arterial hypertension. Perawatan dilakukan selama 4 minggu, dengan tiap kalinya berendam selama 15 sampai 20 menit dan dilakukan 3 kali setiap minggunya.

Secara rinci, Nasermoaddeli dan Kagamimori (2015) telah merangkum publikasi ilmiah tentang balneoterapi dari tahun 1966 s.d. 2003. Studi klinis tersebut 
menyebutkan manfaat balneoterapi pada kelainan dermatologis, muskuloskeletal kronis (inflamasi dan non-inflamasi), kelainan metabolik, dan psikologis. Balneoterapi menghasilkan efek positif pada penyakit psoriasis, eksim, dan cutaneous microcirculation (kelainan dermatologis); rheumatoid arthritis, spondylitis ankilosa, dan fibrositis (penyakit chronic inflammatory musculoskeletal); Osteoarthritis dan nyeri tulang belakang (penyakit chronic non-inflammatory musculoskeletal); kekentalan darah, agregasi trombosit, plasma lipid, stress hormones, dan plasma homocysteine (kelainan metabolism); depresi dan ketegangan psikologis (kondisi psikologis).

Galvez dkk (2018) menyampaikan ringkasan studi yang paling relevan, berdasarkan orisinalitas penelitian, desain eksperimental dan metodologi pengobatan. Balneoterapi merupakan metode tambahan untuk pengobatan yang cukup efektif pada beberapa jenis peradangan, tulang, dan kelainan metabolisme. Subyek penelitian yang digunakan antara lain pada tikus, monyet, dan manusia. Pada manusia, umumnya penyakit yang diteliti adalah diabetes dan osteoarthritis dengan efek positif yang didapatkan pada subyek penelitian setelah melakukan terapi air panas. Beberapa metode pengobatan dan efek klinis yang dihasilkan antara lain (Galvez dkk, 2018) :
- Diabetes, metode hidroterapi (38 s.d. $42^{\circ} \mathrm{C}$ ) selama 60 kali setiap hari @ 30 menit (pada tikus), 10 kali setiap hari @ 30 menit (pada monyet), dan 18 kali setiap hari @ 30 menit (pada manusia) memberikan efek klinis beruapa pencegahan komplikasi diabetes, peningkatan tekanan darah dan metabolisme glukosa. Selain itu didapatkan penurunan level glukosa plasma puasa dan glycated hemoglobin.

- Osteoarthritis, metode balneoterapi menggunakan air kaya Bikarbonat dan Kalsium (38 s.d. $42^{\circ} \mathrm{C}, 10$ kali setiap hari @ 60 menit atau 39 s.d. $40^{\circ} \mathrm{C}, 21$ kali setiap hari@15 menit)dan metode balneoterapi menggunakan air kaya Sulfur $\left(37^{\circ} \mathrm{C}\right)$ dan Lumpur $46-48^{\circ} \mathrm{C}(12$ kali setiap hari @ 20 menit) yang disertai meminum air sulfur $400 \mathrm{ml} / \mathrm{hari}$, memberikan efek klinis pengurangan rasa sakit; peningkatan kelenturan lutut, kekakuan dan fungsi fisik; dan kualitas hidup yang lebih baik.

\section{ANALISIS DAN HASIL}

Analisis kimia dilakukan terhadap 5 sampel air panas untuk mengetahui karakteristik fluida panas bumi seperti tipe fluida, asal fluida, maupun perkiraan temperatur reservoar. Hasil analisis kimia air panas ditampilkan pada tabel 4.

Tabel 4. Hasil Analisis Kimia Air Panas di Cekungan Kutai (Wita dkk, 2019)

\begin{tabular}{|c|c|c|c|c|c|c|}
\hline \multicolumn{2}{|c|}{ Parameter } & AP Santan Tengah & AP Samboja & AP Tamapole & AP Sanga-sanga & AP Dondang \\
\hline Temp & $\left({ }^{\circ} \mathrm{C}\right)$ & 44,3 & 45,3 & 36,8 & 49,5 & 55,7 \\
\hline $\mathrm{pH}$ & & 6,20 & 6,38 & 7,14 & 7,59 & 8,42 \\
\hline $\mathrm{DHL}$ & $(\mu \mathrm{S} / \mathrm{cm})$ & 1036 & 1656 & 541 & 212 & 3520 \\
\hline $\mathrm{SiO}_{2}$ & \multirow{16}{*}{$(\mathrm{mg} / \mathrm{L})$} & 95,88 & 27,85 & 29,43 & 23,37 & 33,45 \\
\hline $\mathrm{B}$ & & 1,13 & 8,08 & 1,41 & 1,62 & 3,81 \\
\hline $\mathrm{Al}^{3+}$ & & 0,04 & 0,04 & 0,05 & 0,03 & 0,03 \\
\hline $\mathrm{Fe}^{3+}$ & & 0,16 & 1,44 & 0,27 & 0,45 & 0,10 \\
\hline $\mathrm{Ca}^{2+}$ & & 13,21 & 11,86 & 2,41 & 4,10 & 34,1 \\
\hline $\mathrm{Mg}^{2+}$ & & 7,57 & 5,74 & 1,20 & 2,89 & 24,61 \\
\hline $\mathrm{Na}^{+}$ & & 236,65 & 366,26 & 129,62 & 31,88 & 635,4 \\
\hline $\mathrm{K}^{+}$ & & 7,18 & 15,17 & 7,72 & 20,34 & 34,18 \\
\hline $\mathrm{Li}^{+}$ & & 0,14 & 0,21 & 0,01 & 0,03 & 0,10 \\
\hline $\mathrm{As}^{3+}$ & & 0,00 & 0,10 & 0,10 & 0,00 & 0,17 \\
\hline $\mathrm{NH}_{4}^{+}$ & & 1,51 & 4,06 & 1,13 & 1,51 & 15,28 \\
\hline $\mathrm{F}^{-}$ & & 0,27 & 0,19 & 0,31 & 0,46 & 0,26 \\
\hline $\mathrm{Cl}^{-}$ & & 51,44 & 274,34 & 100,00 & 2,00 & 667,2 \\
\hline $\mathrm{SO}_{4}{ }^{2-}$ & & 10,00 & 10,00 & 10,00 & 10,00 & 0,01 \\
\hline $\mathrm{HCO} 3$ & & 569,82 & 547,35 & 232,52 & 132,23 & 838,61 \\
\hline $\mathrm{CO}_{3}{ }^{=}$ & & 0,00 & 0,00 & 0,00 & 0,00 & 0,00 \\
\hline
\end{tabular}




\section{Karakteristik Fluida Panas Bumi}

Hasil plotting pada diagram segitiga $\mathrm{Cl}$ $\mathrm{SO}_{4}-\mathrm{HCO}_{3}$ memperlihatkan bahwa air panas di Cekungan Kutai termasuk dalam tipe bikarbonat (Gambar 9). Hal ini sesuai dengan litologi daerah penyelidikan yang didominasi oleh batuan sedimen. Hasil analisis kimia juga menunjukkan komposisi bikarbonat yang tinggi jika dibandingkan dengan komposisi kimia lainnya (132 s.d $838 \mathrm{mg} / \mathrm{L})$.

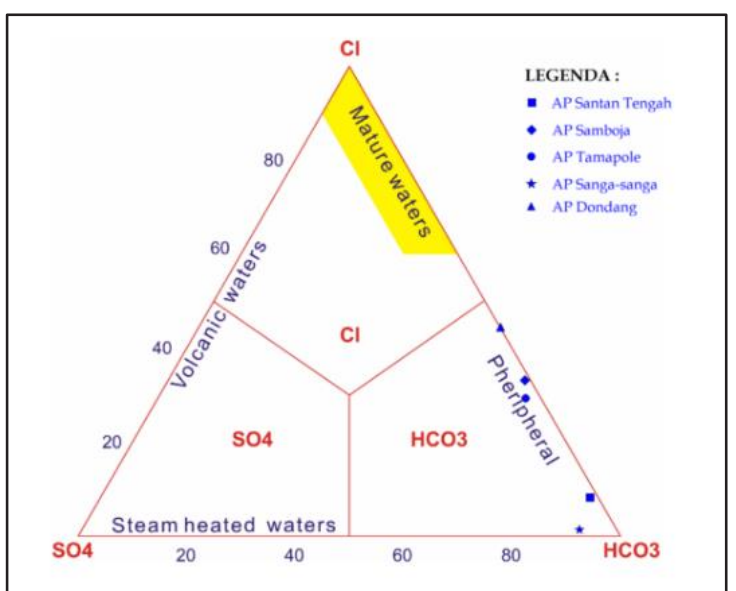

Gambar 9. Diagram segitiga $\mathrm{Cl}-\mathrm{SO}_{4}-$ $\mathrm{HCO}_{3}$

Berdasarkan diagram segitiga $\mathrm{Na} / 1000-$ $\mathrm{K} / 100-\sqrt{\mathrm{Mg}}$, menunjukkan air panas di Cekungan Kutai merupakan Immature Water atau tidak dalam kesetimbangan (Gambar 10). Hal ini menunjukkan pengaruh dari pelarutan batuan lebih dominan dibandingkan kesetimbangan air dengan batuan (Gigenbach, 1988), interaksi air dengan batuan di dekat permukaan (Nicholson, 1993), kemungkinan kesetimbangan pada temperatur yang lebih rendah (Powell dan Cumming, 2010), ataupun pencampuran dengan air permukaan (Rahayudin, 2018) sehingga tidak dapat digunakan untuk perhitungan geotermometer $\mathrm{Na} / \mathrm{K}$ (Gigenbach, 1988).

Berdasarkan diagram segitiga $\mathrm{Cl}-\mathrm{Li}-\mathrm{B}$, air panas di Cekungan Kutai berada di antara zona $\mathrm{Cl}$ dan $\mathrm{B}$, yang menunjukkan lingkungan pembentukan sistem panas bumi di daerah Cekungan Kutai dipengaruhi oleh lingkungan sedimen dengan umur sistem panas bumi relatif sudah tua (Gambar 11). Dari diagram tersebut juga dapat disimpulkan bahwa air panas Tamapole dan Dondang yang berjarak berdekatan diperkirakan mempunyai reservoar yang sama.

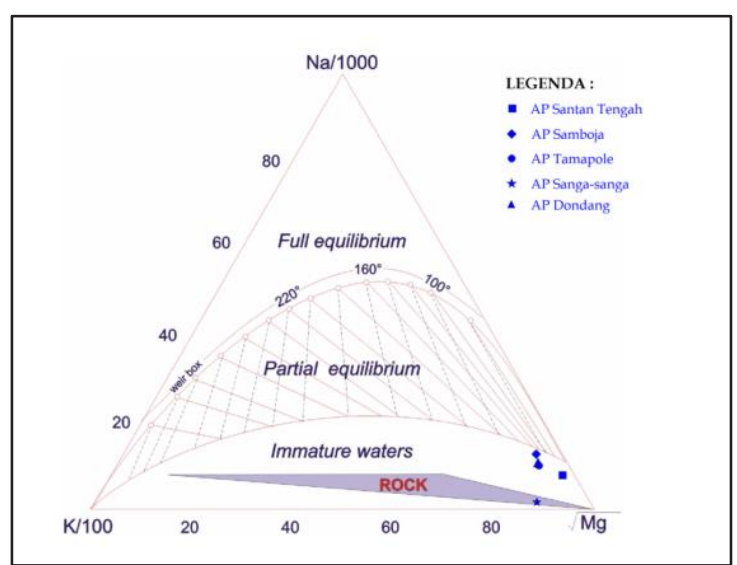

Gambar 10. Diagram segitiga $\mathrm{Na} / 1000-$ $\mathrm{K} / 100-\sqrt{\mathrm{Mg}}$

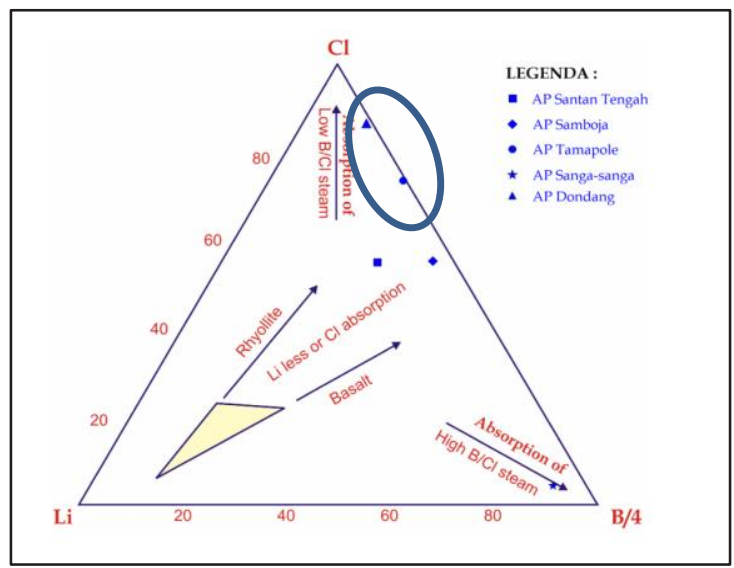

Gambar 11. Diagram segitiga Cl-Li-B/4

\section{Isotop ${ }^{18} \mathrm{O}$ dan ${ }^{2} \mathrm{H}$}

Isotop ${ }^{18} \mathrm{O}$ dan ${ }^{2} \mathrm{H}(\mathrm{D})$ didapat dari empat sampel air panas serta satu sampel air dingin. Nilai $\delta^{18} \mathrm{O}$ berkisar $-6,49$ sampai $7,99 \%$, sedangkan nilai $\delta D$ berkisar 38,99 sampai $-50,4 \%$. Nilai rasio dari sampel air di plot pada grafik $\delta D$ terhadap $\delta^{18} \mathrm{O}$, dengan garis air meteorik $\delta \mathrm{D}=8 \delta^{18} \mathrm{O}$ +14 .

Posisi air panas pada umumnya berada pada garis air meteorik (Meteoric Water Line) yang mengindikasikan bahwa sumber fluida panas bumi berasal dari air meteorik (Gambar 13). Tidak terjadi pengkayaan ${ }^{18} \mathrm{O}$ 
yang signifikan dikarenakan temperatur fluida yang tidak terlalu tinggi sehingga interaksi fluida dengan batuan tidak terjadi dengan intensif.

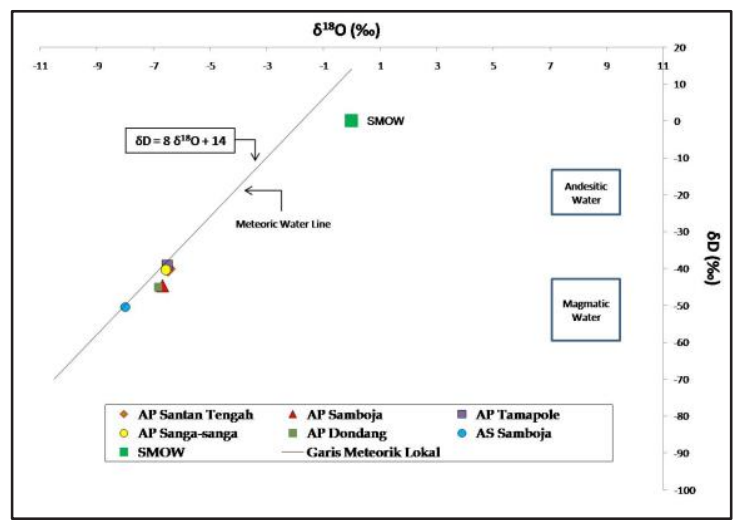

Gambar 13. Grafik isotop $\delta D$ dan $\delta^{18} \mathrm{O}$

\section{Pendugaan Temperatur Bawah Permukaan}

Geotermometri unsur terlarut umumnya digunakan untuk mengestimasi temperatur bawah permukaan dari suatu sistem panas bumi. Hasil perhitungan geotermometer $\mathrm{SiO}_{2}$ memberikan nilai temperatur bawah permukaan sebesar 70 s.d. $130^{\circ} \mathrm{C}$, geotermometer $\mathrm{Na} / \mathrm{K}$ sebesar 150 s.d. $190^{\circ} \mathrm{C}$, dan geotermometer $\mathrm{Na} / \mathrm{K} / \mathrm{Ca}$ sebesar 140 s.d. $170^{\circ} \mathrm{C}$ (tabel 5).

Penggunaan geotermometer silika sangat bergantung pada konsentrasi absolut silika dibandingkan pada rasio konsentrasi, sehingga akan terpengaruh oleh proses di bawah permukaan seperti pendidihan (boiling) dan pengenceran (Nicholson, 1993). Fluida panas di daerah Cekungan Kutai merupakan immature water yang mengalami pencampuran oleh air permukaan, yang menyebabkan konsentrasi silika di air panas tidak mencerminkan konsentrasi silika di reservoir. Oleh karena itu, geotermometer silika kurang tepat digunakan untuk perhitungan geotermometer. Begitu juga dengan penggunaan geotermometer $\mathrm{Na} / \mathrm{K}$. Geotermometer Na-K-Ca lebih tepat digunakan untuk memperkirakan temperatur reservoir karena dapat digunakan pada air hangat/sedikit panas dan immature water (D'Amore dan Arnorsson, 2010). Hal tersebut juga didukung dengan hasil komposisi kimia yang mempunyai nilai $\mathrm{Ca}^{1 / 2} / \mathrm{Na}>1$ (Nicholson, 1993).

Pada sistem panas bumi Santan Tengah diperkirakan mempunyai temperatur bawah permukaan $140^{\circ} \mathrm{C}$, sistem panas bumi Samboja diperkirakan mempunyai temperatur bawah permukaan $150^{\circ} \mathrm{C}$, sistem panas bumi Sanga-sanga diperkirakan mempunyai temperatur bawah permukaan $70^{\circ} \mathrm{C}$, dan sistem panas bumi Tamapole-Dondang diperkirakan mempunyai temperatur bawah permukaan sebesar $170^{\circ} \mathrm{C}$.

Tabel 5. Hasil perhitungan temperatur bawah permukaan

\begin{tabular}{|c|c|c|c|c|c|c|}
\hline PARAMETER & & $\begin{array}{c}\text { AP Santan } \\
\text { Tengah }\end{array}$ & $\begin{array}{c}\text { AP } \\
\text { Samboja }\end{array}$ & $\begin{array}{c}\text { AP } \\
\text { Tamapole }\end{array}$ & $\begin{array}{c}\text { AP Sanga } \\
\text { sanga }\end{array}$ & $\begin{array}{c}\text { AP } \\
\text { Dondang }\end{array}$ \\
\hline T. Air Panas & ${ }^{\circ} \mathrm{C}$ & 44,3 & 45,3 & 36,8 & 49,5 & 55,7 \\
\hline $\mathrm{pH}$ & & 6,20 & 6,38 & 7,14 & 7,59 & 8,42 \\
\hline $\mathrm{T} \mathrm{SiO}_{2}(\mathrm{cc})$ & & 135 & 77 & 79 & 70 & 84 \\
\hline $\mathrm{T} \mathrm{SiO}_{2}(\mathrm{ac})$ & & 131 & 81 & 83 & 74 & 87 \\
\hline T NaK (G) & ${ }^{\circ} \mathrm{C}$ & 152 & 171 & 194 & 442 & 187 \\
\hline T NaK (F) & & 133 & 152 & 176 & 452 & 169 \\
\hline T Na-K-Ca & & 136 & 153 & 167 & 285 & 167 \\
\hline
\end{tabular}




\section{DISKUSI}

Manifestasi panas bumi di Cekungan Kutai berupa mata air panas, $\mathrm{pH}$ netral, dan bertipe bikarbonat sebagai indikasi lingkungan geologinya didominasi oleh batuan sedimen yang kaya karbonatan. Hal ini sesuai dengan litologi di Cekungan Kutai yang didominasi oleh batuan sedimen dengan lingkungan pengendapan deltaik hingga marin. Keberadaan air panas di Kabupaten Kutai Kartanegara pada zona immature water memberikan gambaran bahwa kondisi air panas banyak dipengaruhi oleh air permukaan. Komposisi klorida yang cukup tinggi (51 s.d. $667 \mathrm{mg} / \mathrm{L}$ ) dan hasil plotting diagram Cl-Li-B berada pada zona klorida, mengindikasikan sudah terbentuknya reservoar di kedalaman dengan umur yang relatif tua dan mekanisme pemunculan air panas di permukaan melalui sirkulasi dalam (deep circulation). Air permukaan yang turun ke bawah permukaan terpanaskan oleh batuan panas yang diperkirakan timbul akibat adanya pembebanan dalam waktu yang sangat lama (geopressured), yang kemudian muncul sebagai air panas di permukaan melalui rekahan berupa struktur sesar yang dalam.

Gupta dan Sukanta (2007) menyatakan bahwa sistem panas bumi geopressured terbentuk ketika air panas terperangkap dan terjadi pertukaran atau percampuran dengan batuan sekitarnya. Sistem panas bumi di cekungan sedimen merupakan hasil interaksi dari berbagai sumber panas dan mekanisme pemindahan (transfer) panas dimana panas dari kedalaman dipindahkan ke permukaan. Sistem-sistem panas bumi yang terletak pada cekungan Kutai, diperkirakan berkaitan dengan pembentukan cekungan sedimen yang terisi secara cepat oleh produk sedimentasi, sehingga fluida hidrotermal yang terbentuk mengalami tekanan tinggi. Sistem panas bumi yang berhubungan dengan geopressured ataupun yang berada di lingkungan sedimentasi umumnya memiliki depresi yang sangat tebal, bisa mencapai 5-8 km (Hadi, 2013).
Ketebalan batuan sedimen yang mengisi cekungan ini berimplikasi terhadap nilai gradien termal yang cukup tinggi pada cekungan ini. Gradien termal pada Cekungai Kutai bagian bawah diperkirakan sebesar $90^{\circ} \mathrm{C}$ pada kedalaman $2.000 \mathrm{~m}$ (Gambar 14), diiringi oleh keberadaan mineral smektit yang mulai hilang (Ramdhan dkk, 2010).

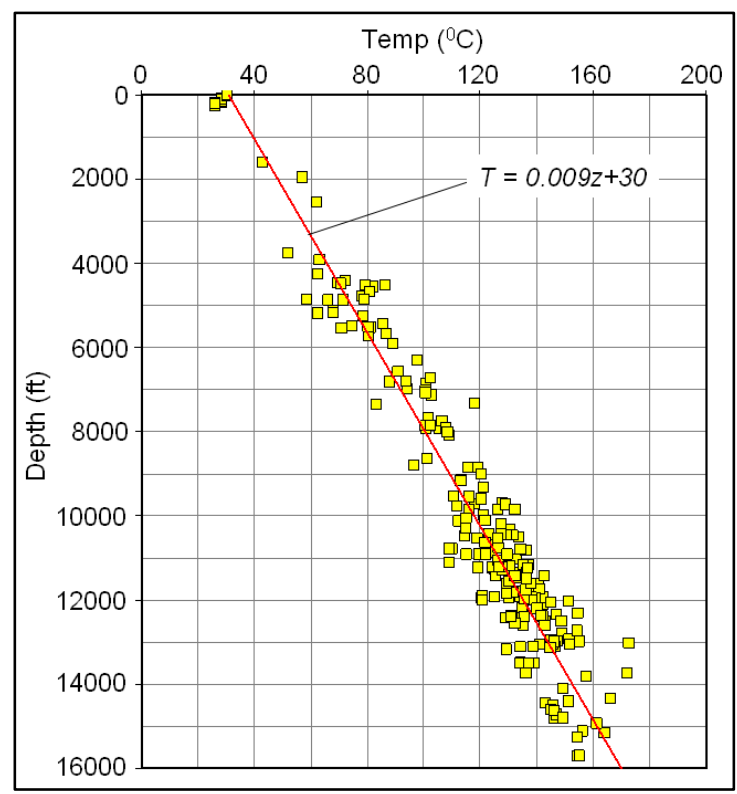

Gambar 14. Kurva gradien termal Cekungan Kutai (Ramdhan, 2010)

Pembentukan sistem panas bumi sangat erat hubungannya dengan siklus hidrologi yang berkesinambungan. Kalimantan memiliki wilayah daratan dengan hutan yang sangat luas. Letak geografisnya sangat menunjang terbentuknya siklus hidrologi di seluruh kawasan dan bahkan dengan curah hujan yang tinggi. Air yang terdapat di permukaan meresap melalui kantong-kantong daerah resapan yang masuk hingga menjangkau akuifer yang paling dalam. Di samping itu, batuan pun mengandung air seperti yang dikenal sebagai connate water atau air yang terperangkap di dalam formasi batuan. Umumnya connate water ini terdapat pada batuan sedimen. Selain itu, terdapat juvenile water atau magmatic water sebagai air yang terperangkap pada batuan magmatik, yaitu air yang terbawa sejak bahan-bahan pembentuk batuan itu 
masih berupa magma. Cekungan sedimen merupakan wadah atau tempat untuk mengakumulasikan fluida tersebut dalam suatu reservoar. Komposisi litologi berjenis lempungan di suatu cekungan sedimen kemungkinan sebagai batuan penutup (cap rock) yang menahan keluarnya panas dan fluida di reservoar.

Di Indonesia sistem panas bumi pada cekungan sedimen ataupun geopressured tidak lepas dari sejarah tektonik setempat, seperti di Kalimantan yang berhubungan dengan jalur subduksi tua. Sumber panas pada sistem panas bumi ini diantaranya dapat berasal dari sisa panas pada batuan terobosan (intrusi) dan faktor pembebanan pada lapisan sedimen dalam, hingga pemanasan dari aktivitas radiogenik pada basement cekungan. Sumber panas dapat juga karena terjadinya pembebanan oleh endapan diatasnya dalam waktu yang relatif singkat pada suatu cekungan, sehingga mengakibatkan terakumulasinya panas yang kemudian menjadi sumber panas pada cekungan tersebut (Jones, 1970; Gupta dan Sukanta, 2007).

Secara umum, sistem panas bumi di Cekungan Kutai mempunyai temperatur reservoar rendah ke sedang dengan temperatur bawah permukaan diperkirakan 70 s.d. $170^{\circ} \mathrm{C}$. Temperatur tertinggi pada sistem panas bumi Tamapole-Dondang dengan perkiraan temperatur bawah permukaan sebesar $170^{\circ} \mathrm{C}$.

\section{REKOMENDASI PANAS BUMI}

\section{PEMANFAATAN}

Sistem panas bumi di Cekungan Kutai dapat dimanfaatkan secara tidak langsung menjadi energi listrik maupun secara langsung. Mengingat temperatur reservoarnya tergolong pada temperatur rendah-sedang, maka pemanfaatan menjadi energi listrik masih terbatas pada penggunaan siklus biner (binary cycle).
Sedangkan pemanfaatan langsung panas bumi dapat di aplikasikan pada sektor perikanan, agro-industri, ataupun pariwisata.

Pemanfaatan panas bumi baik secara langsung ataupun tidak langsung, tentunya membutuhkan fluida panas yang kontinyu. Kebutuhan fluida panas ini bisa didapatkan dengan cara pemboran ataupun langsung dari manifestasi di permukaan. Pada pemanfaatan tidak langsung menggunakan siklus biner, kebutuhan fluida panas diperoleh dengan cara pemboran dalam hingga ke reservoir untuk mendapatkan temperatur optimum yang dibutuhkan. Pada pemanfaatan langsung untuk pengeringan, kebutuhan fluida panas dapat dipenuhi baik secara langsung dari manifestasi ataupun dengan pemboran. Pengambilan fluida panas langsung dari manifestasi dapat dimungkinkan karena temperatur manifestasi mencukupi dalam hal kebutuhan panas yang dibutuhkan untuk aplikasi pengeringan (tabel 3). Kebutuhan fluida juga dapat dipenuhi dengan cara pemboran sumur dangkal ke dalam reservoir di dekat permukaan. Penentuan titik bor tersebut dapat dilakukan dengan metode geofisika seperti geolistrik untuk mencari letak reservoir dangkal tersebut. Pada pemanfaatan langsung untuk akuakultur, pariwisata, dan balneoterapi kebutuhan fluida panas dapat dipenuhi langsung dari manifestasi.

Pemanfaatan langsung panas bumi erat kaitannya dengan kebutuhan dan hasil komoditas dari daerah setempat. Menurut BPS Kabupaten Kutai Kartanegara (Kukar) tahun 2021, hasil bumi daerah Kukar didominasi oleh kopra, kelapa sawit, kopi, kemiri, dan gula aren sehingga pemanfaatannya dapat diaplikasikan untuk komoditas tersebut. Rekomendasi pemanfaatan panas bumi untuk daerah Cekungan Kutai ditampilkan pada Tabel 6. 
Tabel 6. Rekomendasi Pemanfaatan Panas Bumi di Cekungan Kutai

\begin{tabular}{|c|c|c|c|c|c|}
\hline \multirow[b]{2}{*}{ No } & \multirow[b]{2}{*}{ Air Panas } & \multirow{2}{*}{$\begin{array}{c}\text { T. } \\
\text { Reservoir } \\
\left({ }^{\circ} \mathrm{C}\right)\end{array}$} & \multicolumn{2}{|c|}{$\begin{array}{l}\text { Rekomendasi } \\
\text { Pemanfaatan }\end{array}$} & \multirow[b]{2}{*}{ Keterangan } \\
\hline & & & Langsung & $\begin{array}{c}\text { Tidak } \\
\text { Langsung }\end{array}$ & \\
\hline 1 & $\begin{array}{l}\text { Tamapole- } \\
\text { Dondang }\end{array}$ & 170 & $\begin{array}{l}\text { Pariwisata, } \\
\text { Akuakultur, } \\
\text { Agroindustri, } \\
\text { Balneoterapi }\end{array}$ & $\begin{array}{l}\text { Siklus } \\
\text { biner }\end{array}$ & $\begin{array}{l}\text { - Akuakultur : ikan tropis, udang, lobster, dan } \\
\text { ganggang } \\
\text { - Agroindustri : pengeringan kopra, kelapa } \\
\text { sawit, dan kemiri } \\
\text { - Balneoterapi : untuk peradangan tulang } \\
\text { karena mengandung bikarbonat }>500 \mathrm{ppm} \text {. }\end{array}$ \\
\hline 2 & Samboja & 150 & $\begin{array}{l}\text { Pariwisata, } \\
\text { Akuakultur, } \\
\text { Agroindustri, } \\
\text { Balneoterapi }\end{array}$ & $\begin{array}{l}\text { Siklus } \\
\text { biner }\end{array}$ & $\begin{array}{l}\text { - Akuakultur : ikan tropis, udang, lobster, dan } \\
\text { ganggang } \\
\text { - Agroindustri : pengolahan gula aren serta } \\
\text { pengeringan kopra, kelapa sawit, dan kopi } \\
\text { - Balneoterapi : untuk peradangan tulang } \\
\text { karena mengandung bikarbonat }>500 \text { ppm. }\end{array}$ \\
\hline 3 & $\begin{array}{l}\text { Santan } \\
\text { Tengah }\end{array}$ & 140 & $\begin{array}{c}\text { Pariwisata, } \\
\text { Akuakultur, } \\
\text { Agroindustri, } \\
\text { Balneoterapi }\end{array}$ & - & $\begin{array}{l}\text { - Akuakultur : ikan tropis, udang, lobster, dan } \\
\text { ganggang } \\
\text { - Agroindustri : pengeringan kopra dan kelapa } \\
\text { sawit } \\
\text { - Balneoterapi : untuk peradangan tulang } \\
\text { karena mengandung bikarbonat }>500 \text { ppm. }\end{array}$ \\
\hline 4 & $\begin{array}{l}\text { Sanga- } \\
\text { sanga }\end{array}$ & 70 & $\begin{array}{l}\text { Pariwisata, } \\
\text { Akuakultur }\end{array}$ & - & $\begin{array}{l}\text { Akuakultur : ikan tropis, udang, lobster, dan } \\
\text { ganggang }\end{array}$ \\
\hline
\end{tabular}

\section{KESIMPULAN DAN SARAN}

Sistem panas bumi di Cekungan Kutai tergolong pada sistem panas bumi temperatur rendah-sedang dengan kisaran temperatur reservoar 70 s.d. $170^{\circ} \mathrm{C}$. Pembentukan sistem panas buminya diperkirakan berhubungan dengan proses sedimentasi (syn-genetic) dan geopressured. Beberapa air panas keluar melalui sumur pemboran minyak dan masih mengalir hingga saat ini. Hal tersebut menunjukkan bahwa sistem panas bumi sudah terbentuk di bawah permukaan dan siklus hidrologinya masih berjalan dengan baik.

Melihat dari karakteristik fluida panas bumi di Cekungan Kutai dan potensi sumber daya alamnya, maka ada beberapa rekomendasi pemanfaatan panas bumi yang dapat diaplikasikan (tabel 6). Pemanfaatan langsung seperti untuk akuakultur, pengeringan, pariwisata, dan balneoterapi dapat diaplikasikan pada semua sistem panas bumi di Cekungan Kutai. Pada sistem panas bumi Santan Tengah, Samboja, dan TamapoleDondang sangat memungkinkan dimanfaatkan untuk balneoterapi terhadap penyakit peradangan tulang karena memiliki kandungan bikarbonat yang tinggi $(>500$ ppm). Ada peluang untuk pemanfaatan tidak langsung menjadi energi listrik menggunakan siklus biner, yaitu pada sistem panas bumi TamapoleDondang $\left(170^{\circ} \mathrm{C}\right)$ dan Samboja $\left(150^{\circ} \mathrm{C}\right)$.

Perlu adanya kajian lebih lanjut terhadap komposisi kimia dari masing-masing air panas terkait kemungkinan adanya skaling kalsit pada fasilitas produksi yang dapat mengurangi efisiensi, mengingat tingginya kandungan bikarbonat pada air panas tersebut.

\section{UCAPAN TERIMA KASIH}

Penulis pertama ${ }^{(1)}$ merupakan kontributor utama dari makalah ini. Penulis mengucapkan terima kasih kepada Pusat 
Sumber Daya Mineral Batubara dan Panas bumi atas terlaksananya kegiatan kajian sistem panas bumi di Kabupaten Kutai Kartanegara pada tahun 2018. Penulis juga mengucapkan terima kasih kepada Dinas Energi dan Sumber Daya Mineral Kabupaten Kutai Kartanegara atas bantuannya kepada tim kajian selama berada di Lapangan, rekan-rekan di Bidang Panas Bumi, dan tim editor atas koreksi, saran, dan masukannya dalam perbaikan makalah ini.

\section{DAFTAR PUSTAKA}

Abdullah, K., dan Gunadnya, I.B.P., 2010. Use of Geothermal Energy for Drying and Cooling Purposes. Proceedings World Geothermal Congress 2010, Bali.

Angelino, L., dan Barrera, F., 2019. Accelerating geothermal heat adoption in the agri-food sector. The International Renewable Energy Agency (IRENA) Report, Abu Dhabi.

Anonim, 2009. Peta Cekungan Sedimen Indonesia Berdasarkan Data Gaya Berat dan Geologi. Badan Geologi, Bandung.

Anonim, 2020. Peta Sebaran Panas Bumi Indonesia, Badan Geologi, Bandung.

Anonim, 2021. Kabupaten Kutai Kartanegara Dalam Angka, BPS Kabupaten Kutai Kartanegara.

Chandrasekharam, D., dan Bundschuh, J., 2008. Low Enthalpy Geothermal Resources for Power Generation. CRC Press, pp. 101-102.

D'Amore, F., dan Arnorsson, S., 2000. Geothermometry, In Isotopic and Chemical Techniques in: Geothermal Exploration, Development and Use, Edited by $S$. Arnorsson, IAEA, Vienna, 152-199.

Darvish, K., Ehyaei, M. A., Atabi, F., dan Rosen, M. A., 2015. Selection of Optimum Working Fluid for Organic Rankine Cycles by Exergy and Exergy-Economic Analyses. Journal Sustainability No 7.
Galvez, I., Torres-Piles, S., dan OrtegaRincon, E., 2018. Balneotherapy, Immune System, and Stress Response: A Hormetic Strategy. International Journal of Molecular Sciences.

Gazo, F. dan Lind, L., 2010. Low Enthalpy Geothermal Energy - Technology Review, GNS Science Report 2010/20. 58 p.

Giggenbach, W.F., 1988. Geothermal solute equilibria: derivation of $\mathrm{Na}-\mathrm{K}-$ $\mathrm{Mg}-\mathrm{Ca}$ geoindicators. Geochimica et Cosmochimica Acta, 52, 2749-2765

Gupta, H., dan Sukanta, R., 2007. Geothermal Energy, An Alternative Resource for the 21st Century, Amsterdam, the Netherlands; Boston : Elsevier.

Hadi, M.N., 2013. Panas Bumi NonVulkanik di Indonesia. GEOMAGZ, Vol 3 No 3, Bandung.

Hadi, M.N., dan Wibowo, A.E.A., 2014. Panas Bumi Nirgunungapi di Kalimantan. GEOMAGZ, Vol 4 No 1, Bandung.

Hidayat S., dan Umar I., 1994. Peta Geologi Lembar Balikpapan, Kalimantan, Pusat Penelitian dan Pengem-bangan Geologi, Bandung

Hromádka, A., dan Martinek, Z., 2017. Overview Of The Organic Rankine Cycles And Their Current Utilization: Verification Of Several Current ORC's Utilization By The Software Dymola. Conference Paper, DOI: 10.1109/EPE.2017.7967272.

Jones, P.H., 1970. Geothermal resources of the Northern Gulf of Mexico basin. In: Proceedings of the U.N. Symposium on the Development and Utilization of Geothermal Resources. Geothermics, Special Issue, 2 (1), 14-26.

Kalina, A., Leibowitz, H., Lazzori, L., dan Diotti. F., 1995. Recent development in the application of Kalina cycle for geothermal plants. Geothermal Resources Council. 
Karimi, M. N., Dutta, A., Kaushik, A., Bansal, H., dan Haque, S.Z., 2015. A Review of Organic Rankine, Kalina and Goswami Cycle. International Journal of Engineering Technology, Management and Applied Sciences, Vol 3.

Kopunicova, M., 2009. Feasibility Study of Binary Geothermal Power Plant in Eastern Slovakia; Analysis of ORC and Kalina Power Plant. The School for Renewable Energy Science, Iceland, pp. 26-28.

Lund, J.W., dan Boyd, T.L., 2015. Direct Utilization of Geothermal Energy 2015 Worldwide Review. Proceedings World Geothermal Congress 2015, Melbourne, Australia.

Mirolli, M., Hjartarson, H., Mlcak, H.A., dan Ralph, M., 2002. Testing and Operating Experience of the $2 \mathrm{MW}$ Kalina Cycle Geothermal Power Plantin Húsavík, Iceland. OMMI Vol. 1 , Issue 2.

Marini, L., 2001. Geochemical Techniques for the Exploration and Exploitation of Geothermal Energy. Dipartimento per lo Studio del Territorio e delle sue Risorse, Università degli Studi di Genova, Italy.

Nasermoaddeli, A., dan Kagamimori, S., 2005. Balneotherapy in Medicine: A Review. Environmental Health and Preventive Medicine vol 10, page 171-179, July 2005.

Nicholson, K., 1993. Geothermal Fluids; Chemistry and Exploration Techniques. Springer-Verlag, Berlin.

Popovski, K., 2009. Agricultural and Industrial Uses of Geothermal Energy in Europe. Proceedings of the International Conference on National Development Of Geothermal Energy Use, Slovakia.

Powell, T., dan Cumming, W., 2010 Spreadsheets for geothermal water and gas geochemistry. In: Proceedings 35th Workshop on Geothermal Reservoir Engineering. Stanford University. Stanford, California, USA.
Rahayudin, Y., Kashiwaya, K., Susmanto, A., Tada, Y., Iskandar, I., and Koike, K., (2018). Estimation of Fluid-rock Interaction Process and Recharge Area of the Tampomas Geothermal Field, West Java, Indonesia by Water Chemistry, Proceedings 43rd Workshop on Geothermal Reservoir Engineering Stanford University.

Ramdhan, A.M., 2010. Overpressure And Compaction In The Lower Kutai Basin, Indonesia. Doctoral Thesis, Durham University.

Renz, M. dan Engelhard, M., 2006. The New Generation of Kalina Cycle. Conference on Electricity Generation from Enhanced Geothermal System. $\mathrm{M}+\mathrm{W}$ Zander, Strasbourg, France.

Saemundsson, K., Axelsson, G., dan Steingrímsson, B., 2011. Geothermal System in Global Perspective. Short Course on Geothermal Drilling, Resource Development and Power Plants, UNU-GTP, Iceland.

Satyana, A.H., dan Darman, H., 2000. Kalimantan. dalam Outline of the geology of Indonesia, Chapter 5, Indonesian Association of Geologists (IAGI), Jakarta, p. 69-90.

Siswosidjojo, S.S., 2012. Balneoterapi di Sumber Air Panas Alami. GEOMAGZ, Vol 2 No 3, Bandung.

Vaccaro, M., 2013. Multidisciplinary Approach For The Sustainable Utilization Of Medium-Low Temperature Geothermal Resources. PhD Thesis, Universita di Pisa, Italia.

Van Nguyen, M., Arason, S., Gissurarson, M., dan Pálsson, P.G., 2015. Uses of Geothermal Energy in Food and Agriculture - Opportunities for Developing Countries. Food and Agriculture Organization of United Nation (FAO), Roma, Italia.

Wita, L.M., Syafri, I., Yoseph, B., dan Wibowo, A.E.A., 2019. Karakteristik Hidrokimia Untuk Mengetahui Sistem Dan Pemanfaatan Fluida Panas Bumi Daerah Kutai Kartanegara, Kalimantan Timur. Padjajaran Geoscience Journal, Vol 3 No 5, Bandung. 


\section{MAKALAH ILMIAH}

Yanagisawa, N., Muraoka, H., Sasaki, M., Sugita, H., loka, S., Sato, M., dan Osato, K., 2012. Starting Field Test of Kalina System Using Hot Spring Fluid in Japan. Proceedings, ThirtySeventh Workshop on Geothermal Reservoar Engineering, Stanford University, Stanford, California.
Zajuli, M.H.H., Irawan, D., Permana, A.K., Kusworo, A., Wahyudiono, J., Hamzah, A., Saragih, R., Hermanto, B., Firdaus, M., dan Arifin, A.S., 2015. Karakteristik Serpih Gas (Shale Gas) dan Potensinya di Cekungan Kutai dan Cekungan Akimeugah. Kolokium Pusat Survei Geologi, Bandung.

\begin{tabular}{|ll|}
\hline Diterima & $: 2$ November 2020 \\
Direvisi & $: 2$ Desember 2020 \\
Disetujui & $: 31$ Agustus 2021
\end{tabular}

